\title{
THE HUNGER GAMES IS A UTOPIA? \\ THE FEMININE AS A BRIDGE TO THE RETURN TO NATURE IN CONTEMPORARY DYSTOPIA
}

\author{
OS JOGOS VORAZES É UMA UTOPIA? \\ O FEMININO COMO PONTE PARA O RETORNO À \\ NATUREZA NA DISTOPIA CONTEMPORÂNEA
}

\section{Ânderson Martins Pereira*}

\begin{abstract}
Contemporary dystopia has distinguished itself from the canonic texts of the genre since it has problematized technology and is permeated by posthumanism. This update in the dystopian genre has a utopic subtext within the narrative. In it, utopia is only achieved by a return to nature; such a connection between humanity and nature will only be restored by the feminine who will work as a bridge to a posthuman relation among species. This paper will start from the contributions of Derrida (1997, 2008), Dunja M. Mohr (2007), Rita Terezinha Schmidt (2017) and Cary Wolfe (2009) to analyze the trilogy Hunger Games (2008, 2009, 2010), aiming to discuss epistemologically the utopic subtext. The paper will show that Rue and Katniss will create a strong bond with nature, being the last female character responsible to lead society to a posthuman utopic place.
\end{abstract}

Keywords: posthumanism; dystopia; utopia; feminine; nature.

\section{RESUMO}

A distopia contemporânea distingue-se dos textos canônicos do gênero, uma vez que problematiza a tecnologia e é permeada pelo pós-humanismo. Esta atualização no gênero distópico possui um subtexto utópico na narrativa. Nela, a utopia só é alcançada por um retorno à natureza; tal conexão entre a humanidade e a natureza só será restaurada pelo feminino que funcionará como uma ponte para uma relação pós-humana entre as espécies. Este trabalho partirá das contribuições de Derrida (1973), Dunja M. Mohr (2007), Rita Terezinha Schmidt (2017) e Cary Wolfe (2009) para analisar a trilogia Jogos Vorazes $(2008,2009,2010)$, com o objetivo de discutir epistemologicamente o subtexto utópico. O artigo mostrará que Rue e Katniss criarão um forte vínculo com a natureza, sendo a última personagem feminina responsável por guiar a sociedade a um lugar utópico pós-humano.

Palavras-chave: Pós-humanismo; distopia; utopia; feminino; natureza.

\footnotetext{
* Universidade Federal do Rio Grande do Sul. Porto Alegre, RS. Brasil. andersonmrtinsp@gmail.com, https://orcid.org/0000-0003-2667-8891

Doutorando do Programa de Graduação em Letras da UFRGS. Orientadora: Rita Terezinha Schmidt.

1. O presente trabalho foi realizado com apoio da Coordenação de Aperfeiçoamento de Pessoal de Nível Superior - Brasil (CAPES) - Código de Financiamento 001
} 


\section{INTRODUCTION}

Contemporary dystopias have distinguished themselves from canonic ones because they do not discuss social issues centrally, but question the use of technology and the possibility of their interference in a so-called human essence in posthuman and transhuman realities. Regardless of which philosophical current or how imbricated the trans and post-human elements are in the creation of these dystopian societies, one can punctuate a recurrence of the technological element as a trigger for the overthrowing of the social system and humanity as a concept. Although the genetic editing done by many contemporary dystopias is impossible to be undone, these works do not characterize themselves as anti-utopias and messengers of an inescapable future; what happens in them is diametrically the opposite. Thus, we try to show that contemporary dystopias are permeated by a utopian subtext that lies in the abandonment of technology and the return to nature. This utopian space is also permeated by post-humanism, but concerned with the present, representing a long critique of humanism, seeking to disrupt dualisms of which modern society is heir, among which one can mention human/ animal or Culture /Nature.

The present paper will start out from two distinct approaches within posthumanism: one linked to the dystopic text and the second, which will receive more emphasis, to the utopian subtext. Further, this paper aims to show that the bridge between dystopia and this utopian post-human space occurs through women - which can be observed by the large incidence of female main characters in contemporary dystopia (DAY; GREEN-BARTEET; MONTZ, 2014). Thus, in addition to theoretically legitimizing the existence of the utopian space in contemporary dystopias, the paper will discuss the motivation of the feminine as an element of connection to the utopic subtext, as well as the dichotomy between women and nature. It is perceived that by placing the feminine as an element of restoration between humanity and nature, women do not reaffirm certain binarisms conveyed by society, in which men would be linked to culture and women to nature. Conversely, these women establish a relationship with nature in new terms and guide humanity to a posthuman relation among the beings on the planet.

I intend to investigate to what extent the abovementioned choice of the feminine as a bridge to posthuman relations to nature corroborates with a monolithic view of women as natural in opposition to men as civilized, reasonable and connected to culture. I believe that, if that were the case, it would affect the prerogatives of the contemporary dystopian genre, which I connect with deconstruction theory and posthumanism. In order to do so, I chose, as a subject of analysis, the trilogy 
The Hunger Games written by Suzane Collins and comprised of The Hunger Games (2008), Catching Fire (2009), and Mockinjay (2010). The decision was made upon understanding the importance of the narrative in contemporary dystopia. The Hunger Games has inspired many dystopian novels, which partook the discussion of the maladies of technology and an idyllic return to nature on a posthuman basis. Therefore, I believe that this trilogy is responsible for starting the discussion we aim to cover and has one of the most emblematic female main characters of the genre, Katniss Everdeen.

\section{CONTEMPORARY DYSTOPIA, ITS UTOPIAN SUBTEXT AND AND POSTHUMANISM}

It is important to introduce the contemporary dystopian genre and some concepts that are hitched to it. The name dystopia was first used by philosopher John Stuart Mill in one of his lines in the English parliament in 1868; the concept, however, only gained some prominence in the twentieth century. Dystopia is traditionally a genre essentially rooted in society, and among its most striking characteristics are the discussion of ethical or moral values and the denouncement of their possible misrepresentations.

The contemporary dystopias do not begin with social issues, but from a posthuman nightmare, they depict societies in which the human as we know collapse. We believe that the philosophical discussion raised by posthumanism serve as a basis for the idealization of the contemporary dystopian societies. Eduardo Marks de Marques (2013) claims that there is a shift in the focus of dystopia that was previously on the discussion of the social and later shifts to the discussion of the body as a product. In such discussion, Marks de Marques also points posthumanism as an element present in the contemporary narratives from the last thirty years.

In this scenario, Dunja M. Mohr (2007), in her text titled "Transgressive Utopian Dystopias: The Postmodern Reappearance of Utopia in the Disguise of Dystopia", suggests that utopia has endured in the contemporary dystopias (MOHR, 2007, p.7). The author says that there is a utopian subtext in current dystopias and qualifies this relation as transgressive since utopia resists within dystopia and both form a continuum. In her text, Mohr simply claims the existence of the continuum, but does not analyze how the relation between utopian and dystopian elements is held. Rafaella Baccolini (2004), in her text titled "The Persistence of Hope in Dystopian Science Fiction", explains how this relation is elaborated in the current dystopian genre: "Utopia is maintained in dystopia, traditionally a bleak, depressing genre with no space for hope in the story, only outside the story: only by considering 
dystopia as a warning can we as readers hope to escape such a dark future." (p.520) For Baccolini, the reader will detect a utopian subtext - a concept made explicit by Mohr (2007) - by understanding the warning of dystopia.

The dialogue between Baccolini and Mohr in the abovementioned texts is important for understanding the continuum idea. Mohr (2007) establishes her thinking from definitions already given by Baccolini and Lymar Tower Sargent (2010). For instance, Baccolini states that the emergence of the contemporary dystopia and its singularity started with the conservative backlash of the 1980s and the triumph of free-market liberalism in the 1990s. Since then, utopia has been both attacked and co-opted. Mohr (2007) uses these temporal landmarks to the beginning of what she calls dystopian-utopian continuum.

Having said that, we rely on Dunja M. Mohr's argument that there is a dystopian-utopian continuum in contemporary dystopia, which does not embody just hope, but the utopic ideal itself. This claim is essential to this paper since it leads to the utopian reappearance, and the utopian subtext is a feature in the contemporary dystopias that we aim to explore. Nevertheless, we believe that posthumanism is of uppermost importance to understand the dystopic text and the utopic subtext in the contemporary genre. In a later article titled "Anthropocene Fiction: Narrating the 'Zero Hour' in Margaret Atwood's MaddAddam Trilogy", Mohr (2017) will also recognize posthumanism as an element to be considered in contemporary dystopia. However, she abandons the concept of a continuum and links the philosophical current with the concept of ustopia, a concept similar to utopianism (See Lymar Tower Sargent (2010), Utopianism: A very brief introduction) which merges utopia and dystopia as concepts, not as literary genres. We believe that the usage of the concept ustopia, which was coined by Margaret Atwood (2011) in her book In other words, is not interesting for a literary critic of contemporary dystopia because it encompasses utopia and dystopia only as ideals disregarding the textual lineage of both genres. We also believe that ustopia starts from an idea of an equal integration between utopia and dystopia, which does not occur in contemporary dystopia. We claim that the term dystopian-utopian continuum, coined by Mohr (2007), is more accurate because in it there is a central dystopian text and a utopian subtext, which best represents the proportions of utopia and dystopia within contemporary dystopia.

Thus, we propose to add posthumanism to Mohr's idea, showing that the current appears in distinct ways in the dystopic text and in the utopic subtext. We intend to focus mainly on how this current permeates the utopic subtext in contemporary dystopias. 
We believe that the posthumanism found in the utopian subtext is manifested in a different way than in the dystopian text. On the dystopic terrain, posthumanism is very connected with technology, being conceived by it. It is through technology that a posthuman society blossoms, and normally the features of that world are made to withdraw power from humanity or to replace humanity by genetically modified humanoids. Posthumanism triggered by technology and connected to different possibilities of future is a well-known field of study, contributions in such posthuman approach having been made by N. Kathrin Hayle (1999), Robert Pepperel (2003), Brent Waters (2006), and William S. Haney (2005), to name a few. In general, this approach is highly connected with a technological feature and disregards the present, speculating philosophical issues about a pressing technological development and the human race.

On the utopic terrain, posthumanism is rooted in today's society. Uncommitted to technology, it deconstructs humanist values and reformulates the human/nature and human/animal dichotomies. In such subtext, utopia is only achieved when humans make an idyllic return to nature and assume a position of sharing and respecting the other living species on the planet. The view of posthumanism not as a futurist and technological current, but rather as a challenge to humanist values and to current binarisms, which were endorsed by it, is seen by scholars such as Cary Wolfe (2003a, 2003b, 2009, 2012), Claire Colebrook (2014), and Stacy Alaimo (2016).

\section{DERRIDA, POSTHUMANISM AND UTOPIAN SUBTEXT}

The approach to posthumanism that we attach to the utopian subtext in contemporary dystopia establishes many connections with Jaques Derrida's deconstruction theory. Carry Wolfe, in the book What is Posthumanism published in 2009, begins with the deconstruction of the binarism human/animal performed by Derrida's (2008) The Animal That Therefore I am.

They have taken no account of the fact that what they call "animal" could look at them, and address them from down there, from a wholly other origin. That category of discourse, texts, and signatories (those who have never been seen by an animal that addressed them) is by far the one that occurs most abundantly. It is probably what brings together all philosophers and all theoreticians as such. At least those of a certain "epoch," let's say, from Descartes to the present, but I shall soon say why the word epoch and even this historicism leaves me quite uneasy or dissatisfied. Clearly, all those (males and not females, for that difference, is not insignificant here) whom I shall later situate in order to back up my remarks, arranging them within the same configuration-for example Descartes, Kant, Heidegger, Lacan, and Levinas-belong to this quasi-epochal category. Their discourses are sound and profound, 
but everything in them goes on as if they themselves had never been looked at, and especially not naked, by an animal that addressed them. (DERRIDA, 2008, p.13)

In the book, Derrida starts out from the image of a cat seeing his body naked to discuss how the human/animal binary was constructed. He argues that this binary has permeated many philosophers and detects this thinking located in the bible when Adam had the duty to name the animals and therefore objectify them. Derrida considers the singularity of all different species and claims that there is no legitimate reason to level humans above animals. Cary Wolfe (2009) will defend that

[a]s Derrida's point earlier suggests, it requires us to attend to that thing called "the human" with greater specificity, greater attention to its embodiment, embeddedness, and materiality, and how these in turn shape and are shaped by consciousness, mind, and so on. It allows us to pay proper attention, with Maturana and Varela, to the material, embodied, and evolutionary nature of intelligence and cognition, in which language, for example, is no longer seen (as it is in philosophical humanism) as a well-nigh magical property that ontologically separates Homo sapiens from every other living creature. (WOLFE, 2009, p.120)

We can infer in the passage above that one of the main characteristics of posthumanism is the inquiry about certain ethics rooted in the humanism. Cary Wolfe, in another book titled Zoontologies: The question of the animal, will question the ethics behind the human and animal binary and the vicious relation with human and nature, showing that human ethics has always privileged humans to the detriment of animals.

In this scenery, it is necessary to highlight the political aspects regarding posthumanism and the utopian subtext since the genre in which it is located is very much concerned about politics and society. In this sense, Stacy Alaimo (2016) discusses, in her book Exposed: Environmental Politics and Pleasures in Posthuman Times, the necessity of posthumanist thinking in nowadays' society.

The taking of the land for a terra mullius, an empty earth, has underwritten the assault on Native American people and nonhuman habitats, spawning a multitude of placeless places - no laces - that are hardly utopian. Although people who are not Diné are not the intended audience for this blessing, the repetition of the condition of being placed provokes broader questions about inhabitation and ethics. [...] Would it be possible to redesign the domestic with an ethics of inhabiting such that the domestic does not domesticate and the walls do not disconnect? An ethics of inhabiting revels in the pleasure of interconnection and the joy of the unexpected; it embraces the possibilities of becoming in relation to a radical otherness that has been known as "nature." (p. 17-18)

Alaimo suggests that posthumanism is concerned with ethics and that it is necessary to review human practices towards nature. She detects a society and 
a planet that is sick, that needs to demolish an ethical view that departs from an ethical view based on humanist exclusive and divisional ideals. The utopian subtext, here introduced, starts from that same critique and presents a return to nature as well as a deconstruction of binarism, believing that utopia is only achieved when humans overcome essentialist ideas.

This process of deconstruction is not limited to the human/nature binary, but goes further in many dichotomies such as local/global, nature/culture, etc. This feature is connected to the approach to posthumanism we aim to explore in the utopian subtext since this utopic proposal begins with such deconstruction. Jacques Derrida is of paramount importance in dealing with this concept. He argues, in Grammatology (1997 [1976]), that there is a metaphysical tendency in Western philosophy, which desires for immediate access to meaning, and thus has built a metaphysics based on privileging presence over absence. Therefore, we have antagonistic concepts: one representing essence and the other absence, such as human/animal or man/woman. The human is the essence, the animal is the absence, and in the man/woman paradigm, men are seen as essence and privileged over women.

\section{FEMININE AND NATURE: TWO ABSENCES OR TWO EMBODIMENTS OF LIFE?}

In a society in which masculine discourse prevails, the feminine will eventually be considered as an "other", notion coined by Simone de Beauvoir, author of The Second Sex, published originally in 1949. In her book, Beauvoir introduces her idea of "the other" placing man in a converse idea: the subject (2010[1949], p. 17). The masculine figure starts, then, to be recognized by its essentiality, in Beauvoir words "Humanity is male, and man defines woman, not in herself, but in relation to himself" (2010 [1949], p. 50). Therefore, the author stresses that women are not thinkable without man, but only since/from them. Reflecting about the involvement of individuals in domestic chores, the psychoanalyst and sociologist Nancy Chodorow (1978), in The Reproduction of Mothering: Psychoanalysis and the Sociology of Gender, affirms that the structure of domination in western society has results in the opposition between masculine and feminine. The author argues that "the sense of the feminine self is fundamentally connected to the world, the sense of the masculine self is fundamentally apart from the world" (1978, p. 169).

Thus, the feminine status of "other" is due to the historical cultural determination based on binary social constructions - nature/culture, good/evil, man/woman. In this sense, in building a work that aims at the questioning binary 
oppositions, Jacques Derrida (1976) states the natural unbalance that involves the two terms in the binary. Accordingly, Rita Terezinha Schmidt (2007) postulates that

\begin{abstract}
With the emergence of the so-called "man of reason," a concept-metaphor that constituted the hallmark of the conceptual field associated with modern philosophy and science, nature/ culture dualism was rewritten and re-signified, first in Cartesian rationalism, whose classical formulation Cogito ergo sum threw the body to the order of the mechanical laws of nature - res externa - expelling it definitively from the philosophical field as something that is not subject because it is external to it. It belongs to nature of the sensitive and therefore source of reason obscurity. (SCHIMIDT, 2017, p.394; my translation) ${ }^{2}$
\end{abstract}

As noted before, nature and women were relegated to the category of absence. A shallow reading may claim that when it is commissioned to the female to establish a bridge from humanity to nature, the dualistic view is reinforced that that women are related to nature whereas men are to culture or reason. This correlation has been seen in many historical moments and is based on the idea that everything that has an essence, in Derrida's metaphysics of presence, is related to that same side of the binarism while everything that is conceived as absence has also intrinsic relations with absences, the other side of the binary.

However, it is important to stress that the nature in which utopia blossoms and a utopic return to which is the most fundamental human home is not an absence of reason or culture. The nature in utopia is connected to something basic to humanity, which is life itself. The female approach to nature is a recognition of this feminine, not as absence, but as part of life itself. It is important to see that there is no inversion of binarisms, no pointing to nature and women as essence, but a deconstruction of such opposition and a reconnection to a lost meaning of nature and femininity forbidden in years of patriarchy.

\title{
4. THE HUNGER GAMES: AN ARROW TARGETED TO UTOPIA
}

In this section, I intend to analyze the trilogy The Hunger Games shedding light on the utopic subtext present in the narrative and the femininity that permeates it. Therefore, I will start by introducing the story and the author and, then, proceed with the analysis of some passages that I believe trigger some important points that are worth discussing in order to map out the utopic subtext.

2. Original: "Com a emergência do chamado "bomem da razão", um conceito-metáfora que constituiu a marca registrada do campo conceitual associado à filosofia e à ciência modernas, o dualismo natureza/cultura foi reescrito e ressignificado, primeiramente no racionalismo cartesiano, cuja clássica formulação Cogito ergo sum jogou o corpo para a ordem das leis mecânicas da natureza - res externa - expulsando-o definitivamente do campo filosófico como algo que não é sujeito porque externo a ele, pertence a natureza do sensivel e, portanto, fonte do obscurecimento da razão." 
The Hunger Games is a dystopian trilogy published by Suzzane Collins. The story depicts a literal free-for-all for survival displayed on a TV show. The reasons for such horrid entertainment are rooted in the maintenance of such a society. Panen, the post-apocalyptic territory in which the story takes place, is divided into the Capitol and twelve districts, each producing a unique commodity for the whole society. However, the division of labor products is not fairly shared; the Capitol keeps to itself most of the goods produced and gives the districts only the basics for their subsistence. In order to prevent a rebellion, they take a girl and a boy from each district and make them fight to the death in a televised arena. This elicits hatred among the communities, preventing them from forming alliances against the Capitol, and it is a reminder of its power over their districts.

The books are written by Suzanne Collings, who is an American television writer and author. She is also known as the author of The New York Times bestselling series The Underland Chronicles. Among the many awards she has received, we can stress out three given just for the first book of The Hunger Games: School Library Journal Best Books of 2008, KIRKUS Best Young Adult Book of 2008, and CYBIL Award (2008) - Fantasy and Science Fiction. Other important awards are Best Children's Books of 2009, An American Library Association Top 10 Best Books For Young Adult Selection (2009), and California Young Reader Medal (2011).

As we can see, the majority of the awards received by the author come from the trilogy here analyzed, which shows the impact the narrative had on the literary field in those years as well as now in the contemporary dystopian genre. The Hunger Games does not innovate in terms of being a dystopia that aims at the Young Adult (YA) public; in this sense, we have as an early story for this public The Outsiders written by Susan E. Hinton in 1967. However, Collins' trilogy resets the place and the roles of the feminine in contemporary dystopias. Katniss Everdeen, the main character, has a strong agency and turns into the voice of rebellion; it is a woman that will guide people out of the dystopian society.

As we said in the previous sections, we believe that the female works as a bridge from a dystopic reality to a utopic posthuman ideal in which humans, plants, and other life forms coexist in harmony. In this sense, the first female character to establish explicitly a utopic posthuman connection to nature is Rue. The character is a twelve year-old girl sent to Hunger Games from district 11. Her district is known for growing and harvesting fruits and vegetables, which is why she has always maintained a strong connection with nature. The name Rue itself is a reference to a plant, a genus of strongly scented evergreen subshrubs, and this strong connection with nature will help the child to teach Katniss to listen to the forest and to talk to 
the birds, making the main character strengthen bonds with nature. In the passage below, we can see this relation explicated by the protagonist, who is also narrator of the trilogy.

But I feel as if I did know Rue, and she'll always be with me. Everything beautiful brings her to mind. I see her in the yellow flowers that grow in the Meadow by my house. I see her in the Mockingjays that sing in the trees. But most of all, I see her in my sister, Prim. (COLLINS, 2009, p.61)

The passage above is taken from Catching Fire, the second book of the trilogy, and one can detect in it how strong the bond was that the narrator established with Rue. Moreover, we can see that, because of this relation, Katniss will approximate feminine and nature. She progressively connects the little child to natural elements of upper levels: flowers, meadow, Mockingjays (birds), and, finally, to her sister. The connection between Rue and Prim can be seen superficially as a matter of age -because both have about the same age -or of role - since Katniss played Rue's big sister. However, in the context of the quotation, the connection between Katniss and Rue can also be seen as a linkage of these two young females to nature. It is possible to read Prim and Rue as beings that are/were supposed to blossom in life with maturity, as everything does in nature itself.

Rue does not have time to get to maturity since she is a victim of the arena. In spite of that, in her death, the character asks Katniss to sing a song; the protagonist decides a song of hope.

Deep in the meadow, under the willow

A bed of grass, a soft green pillow

Lay down your head, and close your sleepy eyes

And when again they open, the sun will rise.

Here it's safe, here it's warm

Here the daisies guard you from every harm

Here your dreams are sweet and tomorrow brings them true

Here is the place where I love you. (COLLINS, 2008, p. 238)

Taken from The bunger Games, the first book of the trilogy, the song is a lullaby; and, in the story, while singing the song, Katniss starts to decorate Rue's body with flowers and leaves it unburied on the grass, as a gift to nature. The song partakes in an idyllic place connected to nature. The word "safe" is easily connected to utopia, as is the word "warm", indicating mild weather or welcoming beings. Nevertheless, in the passage, we can add to the word "warm" the meaning of life, a reading that gets more concrete as we go through the next stanza, which brings actual life: "daisies" that guard. Another important aspect is the use of the word "here" in the last four stanzas. In the first four, the song describes an idyllic place, but in the last 
four, the lyric I invites the listener to manifest himself or herself in the dreamed place and feel not how the place would be, but how the place is. What is interesting in this interpretation is that the characters are both in an actual forest, which might indicate that the place is attainable, it is actually there. However, the relation with nature has to change, in order for utopia to be achieved.

The utopic subtext connected to life and to nature is seen as an aspiration and permeates Katniss dreams. In them, the character can fully experience comfort and happiness. However, when she wakes up and sees that the dreamed utopia is distant from her reality, she gets upset.

Sometimes when things are particularly bad, my brain will give me a happy dream. [...] Tonight it sends me Rue, still decked in her flowers, perched in a high sea of trees, trying to teach me to talk to the mockingjays. I see no sign of her wounds, no blood, just a bright, laughing girl. She sings songs I've never heard in a clear, melodic voice. On and on. Through the night. There's a drowsy in-between period when I can hear the last few strains of her music although she's lost in the leaves. When I fully awaken, I'm momentarily comforted. I try to hold on to the peaceful feeling of the dream, but it quickly slips away, leaving me sadder and lonelier than ever. (COLLINS, 2008, p. 239)

In the quotation taken from The bunger Games, the first book of the trilogy, we can see that Katniss' utopic place is filled with melody and nature. Rue is no longer dead even though the child is decked with the flowers that accompanied her in her "funeral". It is a place where the main character will learn how to sing to the birds and how to listen to their answers. This knowledge will be taught by a female character who will sing, and the music will be a connection between her and the other female character (Katniss) as well as between them and nature.

As has been seen, Rue is an important bridge towards nature and will epitomize such connection in Katniss. Still, the protagonist is also a conduit from humanity to a utopic and posthuman place. She tries to change society massively against the tyranny of the Capitol and becomes a symbol of the revolution, a Mockingjay. The history of this bird and its connection with the main character is of paramount importance for understanding the utopic subtext in the narrative.

The Capitol, in order to spy on the conversations of the rebels, created male birds called Jabberjays, in a laboratory. The bird had the ability to listen to a whole conversation, memorize it and, after that, reproducing it clearly to the government. However, the rebels discovered the plan and started having silly and meaningless dialogues. The Capitol was forced to abandon de project, but the Jabberjay found a way to keep living by mating with female mockingbirds and giving birth to the Mockinjays. 


\begin{abstract}
"But Mockingjays were never a weapon," said Madge. "They're just songbirds. Right?" "Yeah, I guess so," I said, But it's not true. A mockingbird is just a songbird. A mockingjay is a creature the capitol never intended to exist. They hadn't counted on the highly controlled jabberjay having the brains to adapt to the wild, to thrive in a new form. They hadn't anticipated its will to live." (COLLINS, 2009, p.92)
\end{abstract}

In the passage above, taken from Catching fire, the protagonist admires the defiance of the animal, and its insubordination geared towards living, finding its space into nature. This story is symptomatic of posthuman features in the dystopic text and also in the utopic subtext, as we shall demonstrate. The Jabberjay was made by technology, which reminds us of the posthumanism conceptualized by Hayles (1999), in which technology is used for editing and creating new consciousnesses or enhancing the ones that already exist. The dystopian text uses technology to create a bleak feature in which there will be a downfall for humans. We can see it in the story of the bird since the Jabberjay is created to be controlled and to maintain the totalitarian social order, in a dystopic landscape.

The contemporary dystopias stress that the only way to avoid these dreadful features is to get rid of technology. The Jabberjay is an icon of such process since it had been conceived by technology, but, in order to survive, had to mate with a natural species, transforming his decedents into a new bird that finds its place in the wild.

The utopic return to nature has its bedrock built on posthuman views, one that levels the playing field for all species since the idea of essence and absence between human and animal no longer exists. This place points to the deconstruction of all binary oppositions, which is, as we have seen, intimately connected to posthumanism in Wolfe's (2009) point of view. The Jaberjay is conceived under the idea of male, reason, culture. However, the female mockingbird is not restrained to these binary views, it has home and belonging in nature. The Mockinjay that results from the encounter of both species is the opening for a utopic path, where the binary oppositions do not matter and the species can integrate and share harmonically the world with other species.

In this sense, Suzan Griffin (2015[1978]), opens her book Woman and Nature: The Roaring Inside Her stating that men have turned their backs to nature.

He says that woman speaks with nature. That she hears voices from under the earth. That wind blows in her ears and trees whisper to her. That the dead sing through her mouth and the cries of infants are clear to her. But for him this dialogue is over. He says he is not part of this world, that he was set on this world as a stranger. He sets himself apart from woman and nature (2015 [1978], p. 27) 
Griffin starts out from a masculine view about women and nature. However, she believes that men feel strange because they see themselves as a superior to women and the other species. Yet, the author believes that, in nature, women have found life, diversity, sharing, and belonging, and these features speak a lot about what it is like to be a woman in the world. (GRIFFIN, 2015 [1978], p. 158])

Griffing points to a figuration of a woman that is empowered by nature and of a man that sets himself apart. This idea is seen in contemporary dystopia, where the utopia is only attained when women guide all humanity back to nature. In this sense, the sex of the birds in the story is also indicative of the masculine lack of connections with nature and the feminine bonds with it. The Jabberjay are males and apart from nature (conceived by technology and not made to go into the wild), the mocking birds are female and are already part of nature, and it will be the latter that will function as a bridge to nature for the male birds.

Katniss will take for herself the cloak of Mockinjay, and will be a symbol of rebellion. "The bird, the pin, the song, the berries, the watch, the cracker, the dress that burst into flames. I am the Mockingjay. The one that survived despite the Capitol's plans. The symbol of the rebellion." (COLLINS, 2009, p.386). We will have a female character that is supposed to lead these people into a happier place. Her connections with Mockinjay are not just the defiance towards the Capitol, but also a harmonic life between humans and nature.

I no longer feel allegiance to these monsters called human beings, despise being one myself. I think that Peeta was onto something about us destroying one another and letting some decent species take over. Because something is significantly wrong with a creature that sacrifices its children's lives to settle its differences. You can spin it any way you like. Snow thought the Hunger Games were an efficient means of control. Coin thought the parachutes would expedite the war. But in the end, who does it benefit? No one. The truth is, it benefits no one to live in a world where these things happen. (COLLINS, 2010, p.377)

The passage above is taken from I Monckinjay, the last book of the trilogy and it shows how problematically the main characters see human existence in the world; she even calls her species monsters. She compares humans with other species saying that humans sacrifice their children, which indicates that she takes nature as a model to be followed. In a superficial reading of the quotation, we can infer that she is mainly discussing how humans treat themselves, disregarding how they behave with other species. However, when the narrator states her agreement to Peeta's idea of human extinction and a more decent species taking over, she believes that humans are not a decent species, and this thinking is regarded to how they treat other forms of life, nature, and the planet as a whole. It is necessary to be decent, to live in harmony, to care about humanity and other species as well. 


\section{CONCLUSION}

Contemporary dystopia stresses problems that may come with the misuse of technology. The futuristic bleak posthuman realities are the major concern of such narratives, whose features are more acute then social and political themes -as it occurred in the canonic dystopias in the past. The view for utopia, as has been seen, is also singular; these narratives do not deny the possibility of utopia, but conceive it as a return to nature. This paper has shown that the utopic subtext that exists in these narratives can be discussed epistemologically. In addition, each narrative draws its own borders for utopia, and the utopian place found in contemporary dystopia has its specific features. The utopia is attained only when humanity returns to nature on a posthuman basis, deconstructing all the binary oppositions, mainly the human/animal one and, therefore, understanding that neither humans are essence nor are animals absence, but both are in the same level and are supposed to share the planet with respect.

In order to create this bridge to nature, the female turns herself into a guide. These narratives depict a female that connects with nature, establishes a connection in new terms in which she does not understate herself or nature as absence, but transcends this dualistic idea and finds empowerment and belonging.

In this sense, The Hunger Games shows strongly how utopia can be attainable. Katniss embodies a message of hope, being herself the symbol of rebellion. She also has a strong relation with nature and that is how she will see problems in the totalitarian government of President Snow and in the government of Coin, the leader of the new government that is taking Snow's place. She questions the human selfish thinking that never comes from a place of sharing, but from an egotistical place that sacrifices life in vain. The only place where she feels comfortable is in nature, apart from wars and blood.

As a subtext, the utopia does not receive the main attention in contemporary dystopia. However, hints of it are easy to be found in the three novels. We conclude by believing that the studies on utopia and dystopia are important for the studies of the genre and its lineage, but also for society, since both concepts are highly permeable to the wishes and fears of a society. Therefore, to see the updates that contemporary dystopia has to offer also helps to understand how our society has evolved its dreams. 


\section{REFERENCES}

ALAIMO, Stacy. Exposed: Environmental Politics and Pleasures in Postbuman Times. Minneapolis: University of Minnesota Press, 2016.

ATWOOD, Margaret. In other words: sf and buman imagination. New York: Doubleday, 2011.

BACCOLINI, Raffaella( 2004). The Persistence of Hope in Dystopian Science Fiction, PMLA, Florianópolis, vol. 119, No. 3, p. 518-521.

BEAUVOIR, Simone de (1949). The second sex. Translated by: Constance Borde; Sheila Molovany-Chevallier. New York:Vintage books, 2010.

CHODOROW, Nancy. The Reproduction of Mothering: Psychoanalysis and the Sociology of Gender. Los Angeles: University of California Press, 1978.

COLEBROOK, Claire. Death of the PostHuman: Essays on Extinction. Michigan: Open Humanities Press, 2014.

COLLINS, Suzanne. The Hunger Games. 1 ed. New York: Scholastic Press, 2008.

COLLINS, Suzanne. Catching Fire. 1 ed. New York: Scholastic Press, 2009.

COLLINS, Suzanne. Mockingjay. 1 ed. New York: Scholastic Press, 2010.

DAY, Sara K.; GREEN-BARTEET, Miranda A.; MONTZ, Amy L.. Female Rebellion in Young Adult Dystopian Fiction. Burlington: Ashgate Publishing Company, 2014.

DERRIDA, Jacques (1976). Of Grammatology. Baltimore: The Johns Hopkins University Press, 1997.

DERRIDA, Jacques. The animal, therefore I am. New York: Fordham University Press, 2008.

GRIFFIN, Susan (1978). Woman and Nature: The Roaring Inside Her. New York: Open Road, 2015.

HANEY, William S. Cyberculture, Cyborgs and Science Fiction: Conciousness and the Posthuman. Nova Your: Rodopi, 2005.

HAYLES, N. Katherine. How We Became Postbuman: Virtual Bodies in Cybernetics, Literature, and Informatics. Chicago: The university of Chicago Press, 1999. 
HINTON, Susan E. The outsiders. New York: Viking Press, 1967.

MARKS DE MARQUES, Eduardo (2013). "God is a cluster of neurons': Neoposthumanism, theocide, theogony and anti-myths of origin in Margaret Atwood's Oryx and Crake". Gragoatá, Niterói, n. 35, p. 155-169.

MOHR, Dunja M(2007). "Transgressive Utopian Dystopias: The Postmodern Reappearance of Utopia in the Disguise of Dystopia". Zeitschriftfür Anglistik und Amerikanistik (ZAA), Vol. 55, No. 1, p. 5-24.

MOHR, Dunja M . (2017). "'Anthropocene Fiction: Narrating the 'Zero Hour' in Margaret Atwood's MaddAddam Trilogy". In: MATHIS-MOSER, Ursula; CARRIÈRE, Marie (ed.). Writing Beyond the End Times?: The Literatures of Canada and Quebec. Innsbruck: Innsbruck UP, p. 25-46.

PEPPEREL, Robert. The Postbuman Condition Conscionsness beyond the brain. Oregon: Intellect Books, 2003.

SARGENT, Lymar Tower. Utopia: A very short introduction. New York: Oxford, 2010.

SCHMIDT, Rita T. Decentramentos/Convergências: Ensaios de Crítica Feminista. Porto Alegre: Editora da UFRGS, 2017.

WATERS, Brent. From Human to Postbuman: Christian Theology and Technology in a

Postmodern World. Burlington: Ashgate, 2006.

WOLFE, Cary. Animal Rites: American Culture, the Discourse of Species, and Posthumanist Theory. Chicago: The University of Chicago Press, 2003a.

WOLFE, Cary. Before the Law: Humans and Other Animals in a Biopolitical Frame. Chicago: The University of Chicago Press, 2013.

WOLFE, Cary. What is Posthumanism?. Minneapolis: University of Minnesota Press, 2010.

WOLFE, Cary. Zoontologies: the question of the animal. Minneapolis: University of Minnesota Press, 2003b.

Recebido: 20/05/2019

Aceito: 6/07/2019

Publicado: 13/08/2019 